\title{
T Helper Type 1/T Helper Type 17-Related Cytokines in Chronic Hepatitis C Patients before and after Interferon and Ribavirin Therapy
}

\author{
Amal Fathy ${ }^{a}$ Amal S. Ahmed ${ }^{a}$ Lobna Metwally ${ }^{b}$ Adel Hassan ${ }^{c}$ \\ Departments of a Clinical Pathology, ${ }^{\mathrm{b}}$ Microbiology and ${ }^{\mathrm{C}}$ Tropical Medicine, Faculty of Medicine, Suez Canal \\ University, Ismailia, Egypt
}

\section{Key Words}

Cytokine $\cdot$ Interferon- $\gamma \cdot$ Interleukin-17 $\cdot$ Hepatitic C virus • Interferon therapy $\cdot$ Ribavirin therapy

\begin{abstract}
Objective: This study examined the T helper (Th) 1/Th17-related cytokines, interferon (IFN)- $\gamma$ and interleukin (IL)-17 in the serum of biopsy-proven chronic hepatitis $C$ patients before and after IFN and ribavirin therapy to address whether or not viral clearance is related to Th1/Th17 cytokines. Subjects and Methods: The serum levels of IFN- $\gamma$ and IL-17 were assayed by ELISA on 26 patients with chronic hepatitic $C$ virus $(\mathrm{HCV})$ infection before the start and 3 months after treatment with pegylated IFN- $\alpha$ plus ribavarin and compared with sera from 15 normal control subjects. Results: IFN- $\gamma$ and IL-17 levels are higher in the serum of patients with chronic hepatitis than in normal controls and these elevated levels were not directly correlated $(r=-0.01, p=0.96$ for IFN- $\gamma$ and $r=-0.08, p=0.66$ for IL-17) to the viremic state of the HCV infection. In contrast to IL-17, IFN- $\gamma$ showed significant reduction after 12 weeks of treatment with pegylated IFN plus ribavirin. However, IFN- $\gamma$ and IL-17 serum levels were not significantly ( $p=0.19$ and $=0.70$, respectively) different among responders and nonresponders for pegylated IFN
\end{abstract}

plus ribavirin therapy. Conclusion: Our findings suggest that the combined treatment with pegylated IFN- $\alpha$ and ribavirin downmodulates the secretion of key cytokine IFN- $\gamma$ as early as 12 weeks after treatment in infected patients. These findings could encourage new exciting possibilities for immunebased interventions with the aim of restoring functional antiviral $\mathrm{T}$ cell responses combined with improved viral clearance.

Copyright $\odot 2011$ S. Karger AG, Basel

\section{Introduction}

The adaptive effector CD4+ T helper (Th)-mediated immune response is highly heterogeneous, based on the development of distinct subsets that are characterized by different profiles of cytokine production. Initially, two polarized forms of Th effectors, type 1 (Th1) or type 2 (Th2), were identified in both mice and humans [1]. Th1 cells produce interferon (IFN) $-\gamma$ and are mainly devoted to protection against intracellular microbes, whereas Th2 cells produce interleukin (IL)-4, IL-5, IL-10, and IL-13 and are involved in the protection against extracellular infectious agents. More recently, a novel subset of Th, which is distinct from Th1 and Th2, and is called Th17,

\section{KARGER}

Fax +4161306 1234

E-Mail karger@karger.ch

www.karger.com
(C) 2011 S. Karger AG, Basel

1011-7571/11/0204-0345\$38.00/0

Accessible online at:

www.karger.com/mpp
Amal Sayed Ahmed, MD

Faculty of Medicine, Suez Canal University

41522 Ismailia (Egypt)

Tel. +20 101703125 , Fax +20 643378524

E-Mail amalnoor@gmail.com 
has been described [2]. Th17 cells are characterized by the ability to secrete IL-17A, IL-17F, IL-21, IL-22, and IL-6 [3]. The ubiquitous expression of IL-17 receptors means that it can act on a broad range of cellular targets. IL-17A and IL-17F function primarily as pro-inflammatory mediators, inducing local production of IL-6, prostaglandin $\mathrm{E}_{2}$, and nitric oxide, and specifically recruiting neutrophils [4]. Th17 cells have been shown to have a protective function in certain bacterial infections [5]. The production of IL-17 has been reported in patients with human immunodeficiency virus infection [6], herpes simplex virus [7] and respiratory syncytial virus infections [8] in rodents. Annunziato et al. [9] identified a subset of cells sharing features of both Th1 and Th17; hence a possible flexibility between Th1 and Th17 cells was suggested.

Hepatitis $\mathrm{C}$ virus (HCV) is an enveloped, approximately 9.6-kb, positive-sense, single-stranded RNA virus and is classified in the family of Flaviviridae. Over 170 million individuals worldwide are infected with HCV [10]. Chronic HCV infection is responsible for inflammation of the liver, and approximately $20 \%$ of patients progress to liver cirrhosis with an increased risk for the development of hepatocellular carcinoma [10]. Currently, a combination therapy including pegylated IFN- $\alpha$ plus ribavirin represents the standard treatment regimen for patients with chronic HCV infection [11]. Early antiviral response to therapy appears to be predictive of response to treatment [12]. Spontaneous clearance of HCV is associated with a vigorous and robust response of CD4+ and CD8+ T cells [13], and several studies have indicated an important role for T cells in antiviral therapy-induced clearance [14]. Rowan et al. [15] reported that specific Th17 cells were induced in HCV-infected patients, and demonstrated that transforming growth factor (TGF)- $\beta$ and IL-10, which are induced by the HCV nonstructural protein 4, suppress Th1 and Th17 responses in HCV-infected patients. This study aimed to assess Th1/Th17-related cytokines (IFN- $\gamma /$ IL-17) in the serum of patients with chronic hepatitis $\mathrm{C}$ infection before and after pegylated IFN- $\alpha$ plus ribavirin therapy compared to normal controls.

\section{Subjects and Methods}

Twenty-six patients [male: 17, female: 10 , duration of hepatic illness: $32 \pm 17$ months (range 20-55)] with chronic hepatitis C were selected from those attending the treatment center of viral hepatitis in Ismailia Hospital, Egypt. A diagnosis of chronic hepatitis was made if the following criteria were present after a 6-month follow-up: significant and persistent symptoms; fluctu- ating or persistently elevated alanine aminotransferase (ALT) and aspartate aminotransferase (AST) ( $>1.5$-fold of normal levels), normal serum albumin and prothrombin time; ultrasonography revealing an enlarged bright texture of the liver \pm portal tract thickening and \pm normal spleen. Liver biopsy was performed to assess hepatic injury using the histological activity index as modified by Ishak [16]. The treatment protocol included: $180 \mu \mathrm{g}$ of pegylated IFN- $\alpha$ given subcutaneously once a week plus ribavirin; the dose of ribavirin was adjusted (1,000-1,200 mg/day) given orally according to the body weight. Patients with a history of hepatotoxic drug, alcohol intake, and previous IFN therapy, or who were co-infected with hepatitis B virus were excluded. Fifteen healthy subjects (male: 11, female: 4) were included. Both patients and controls were age and sex matched. The study was approved by the institutional review board of Suez Canal University. Written informed consent was obtained from all participants.

Venous blood samples ( $7 \mathrm{ml}$ in EDTA and plain tubes) were drawn from each subject for PCR and cytokine testing; serum samples were stored at $-60^{\circ} \mathrm{C}$ until the time of assay. All samples were subjected to the following routine laboratory investigations: complete blood count (CELL-DYN 1700), liver function tests including ALT, AST, total bilirubin, direct bilirubin and serum albumin (HITACHI 912 automatic analyzer, Roche Diagnostics, Mannheim, Germany), $\alpha$-fetoprotein (VIDAS autoanalyzer, bioMérieux, France), and viral hepatitis markers [HCV antibodies and HBsAg (MEIA, Abbott Laboratories)]. Quantitative HCV real-time PCR was performed for the patients before the start of pegylated IFN- $\alpha$ plus ribavrin treatment and at week 12 of treatment to detect the early virological response using a light cyclerRNA master hybridization probe system in accordance with the manufacturer's instruction (Roche Diagnostics). The lower detection limit was $<1,000 \mathrm{IU} / \mathrm{ml}$.

Serum levels of IFN- $\gamma$ and IL-17 were assessed using a commercially available sandwich enzyme immunoassay kit (Quantikine $\mathrm{R} \& \mathrm{D}$ system, USA). The minimum detection limits were $8 \mathrm{pg} / \mathrm{ml}$ for IFN- $\gamma$ and $15 \mathrm{pg} / \mathrm{ml}$ for IL-17.

Statistical analysis was performed using SPSS program version 11. Data are presented as means \pm standard deviation. Independent sample (Student's) t test, paired sample t test and Pearson correlation analysis were used as appropriate. Statistical significance was considered at the $5 \%$ level of probability $(\mathrm{p}<0.05)$.

\section{Results}

Clinical, histological and laboratory parameters of HCV-infected patients and controls enrolled in this study are listed in table 1. Data analysis demonstrated statistically significant differences in platelet counts, ALT, AST, and $\alpha$-fetoprotein between the $\mathrm{HCV}$-infected patients and controls $(\mathrm{p}=0.030, \mathrm{p}=0.003, \mathrm{p}=0.001, \mathrm{p}=0.012$, respectively).

In $\mathrm{HCV}$-infected patients, prior to starting antiviral treatment, the mean baseline level of IFN- $\gamma$ was $51 \pm$ $20 \mathrm{pg} / \mathrm{ml}$ (range 34-135), whereas control subjects' mean level was $40 \pm 4.3 \mathrm{pg} / \mathrm{ml}$ (range $30-47$ ). The mean value 
of IL-17 in HCV-infected patients was $66 \pm 28 \mathrm{pg} / \mathrm{ml}$ (range 39-180), whereas for control subjects, the mean level was $43 \pm 7.0 \mathrm{pg} / \mathrm{ml}$ (range 34-64). The differences between IFN- $\gamma$ and IL-17 levels for HCV patients and control subjects were statistically significant $(\mathrm{p}=0.014$ and $\mathrm{p}=0.001$, respectively).

Three months after starting treatment with pegylated IFN- $\alpha$ plus ribavirin, the mean level of IFN- $\gamma$ was $45 \pm$ $10 \mathrm{pg} / \mathrm{ml}$ (range 32-78), and the mean level of IL-17 was $69 \pm 36 \mathrm{pg} / \mathrm{ml}$ (range 42-240). A statistically significant decrease $(\mathrm{p}=0.03)$ was obtained between the mean values of IFN- $\gamma$ before and after treatment but not for IL-17 $(\mathrm{p}=0.45)$. The levels of IFN- $\gamma$ and IL-17 among responders $(n=19)$ versus nonresponders $(n=7)$ for pegylated IFN plus ribavirin therapy did not show any significant differences ( $\mathrm{p}=0.19$ and $\mathrm{p}=0.70$, respectively).

The correlations between serum IFN- $\gamma$ levels and viremia $(\mathrm{r}=-0.01, \mathrm{p}=0.96)$, grading scores $(\mathrm{r}=-0.27, \mathrm{p}=$ 0.17 ), and fibrosis scores ( $\mathrm{r}=-0.01, \mathrm{p}=0.94)$ were not significant. Nonsignificant correlations were also detected between the serum levels of IL-17 and viremia $(r=-0.08$, $\mathrm{p}=0.66)$, fibrosis scores $(\mathrm{r}=-0.19, \mathrm{p}=0.34)$, and grading scores $(r=-0.41, p=0.23)$. A significant positive correlation between serum levels of IFN- $\gamma$ and IL-17 were detected in controls and $\mathrm{HCV}$-infected patients before and after therapy $(\mathrm{r}=0.57, \mathrm{p}=0.027 ; \mathrm{r}=0.70, \mathrm{p}=0.001$ and $\mathrm{r}=0.61, \mathrm{p}=0.001$, respectively) (fig. 1).

\section{Discussion}

Higher levels of Th1 (IFN- $\gamma$ ) and Th 17 (IL-17) were detected in patients compared to controls as shown previously [17]. Both specific Th17 and Th1 cells are induced against the core protein in HCV infection $[15,18]$.

In chronic HCV infection, a weak CD4+/CD8+ T cell response is observed. This is explained on the basis of the tolerogenic potential of the liver, which may be caused by either a primary $\mathrm{T}$ cell failure in which the dendritic cells fail to stimulate the antigen-specific $\mathrm{T}$ cells, or T cell exhaustion in which virus-specific $\mathrm{T}$ cells become depleted by a continuous high viral load [19].

Loss of functional properties of antiviral T cells comprises a continuum of severity, ranging from mild to severe deficiencies. Mild deficiencies include the failure to produce certain cytokines while the more severe ones include deficiency in cytokine production [20] and inhibition of intrahepatic IFN- $\gamma$ production by HCV NS5A as seen in transgenic mice [21]. Defective IFN- $\gamma$ production by peripheral blood mononuclear cells from $\mathrm{HCV}$-infect-

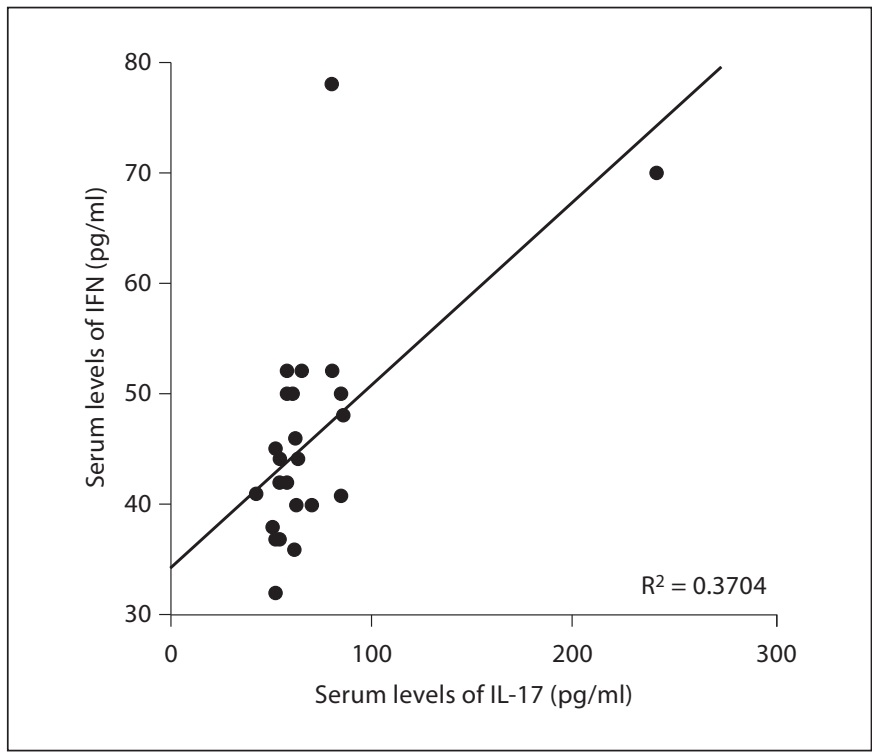

Fig. 1. Scatter diagram showing a significant positive correlation between serum levels of IFN- $\gamma$ and IL-17 in chronic HCV-infected patients after pegylated IFN plus ribavirin therapy.

Table 1. Clinical, histological and laboratory parameters in chronic hepatitis $\mathrm{C}$ patients and controls

\begin{tabular}{lll}
\hline Variables & $\begin{array}{l}\text { Chronic HCV } \\
(\mathrm{n}=26)\end{array}$ & $\begin{array}{l}\text { Contro } \\
(\mathrm{n}=15\end{array}$
\end{tabular}

Risk factors, $\mathrm{n}(\%)$

Blood transfusion

Antibilharzial antibody

Previous surgery

Histology

Grading score

Fibrosis score

Liver function

ALT, U/l

AST, U/l

T-bilirubin, $\mathrm{mg} / \mathrm{dl}$

D-bilirubin, $\mathrm{mg} / \mathrm{dl}$

Albumin, g/dl

$\alpha$-fetoprotein, IU/ml

Viral load

Mean, $\mathrm{IU} / \mathrm{ml} \times 10^{3}$

Minimum, IU/ml

Maximum, $\mathrm{IU} / \mathrm{ml} \times 10^{3}$

Hematological parameters

Hemoglobin, g/dl

WBC count, $\times 10^{3} / \mu \mathrm{l}$

Platelet count, $\times 10^{3} / \mu 1$

$\begin{array}{cc}3(10) & - \\ 20(74) & - \\ 3(10) & - \\ & - \\ 2.8 \pm 1.3 & - \\ 5.5 \pm 2.0 & 17 \pm 5 \\ 46 \pm 22^{*} & 22 \pm 5 \\ 47 \pm 37^{*} & 0.6 \pm 0.2 \\ 0.6 \pm 0.3 & 0.1 \pm 0.1 \\ 0.2 \pm 0.1 & 4.1 \pm 0.7 \\ 4.2 \pm 0.6 & 4.8 \pm 2.1 \\ 9.7 \pm 9.0^{*} & - \\ & \\ 1,041 \pm 1,883 & \\ 16,347 & \\ 9,300,000 & \\ & \\ 14.0 \pm 1.4 & 250 \pm 5 \pm 1.4 \\ 6.4 \pm 1.9 & \end{array}$

$\mathrm{WBC}=$ White blood cells. ${ }^{*} \mathrm{p}<0.05$. Figures are means $\pm \mathrm{SD}$, unless indicated otherwise. 
ed patients in response to nonstructural protein 4 is another example of the severe deficiencies [22].

Hepatitis $C$ also induces immunosuppressive cytokines IL-10 and TGF- $\beta$, which are able to inhibit Th17 and Th1. Neutralization of TGF- $\beta$ has been shown to increase IL-17 production in response to hepatitis $\mathrm{C}$ nonstructural protein 4 [15].

On the other hand, some studies demonstrated that inducing elevated levels of IL-17-producing CD4+ and/or CD8+ T cells may facilitate viral persistence in the host. Hou et al. [23] reported that Th17 cells promote persistent viral infection in a model of chronic virus infection and IL-17 upregulates anti-apoptotic molecules and consequently increases persistent infection by enhancing the survival of virus-infected cells and blocking target cell destruction by cytotoxic T cells. Also, Oyoshi et al. [24] reported that IL-17 contributes to viral replication in a model of disseminated vaccinia infection rather than providing host defense against viral infection.

Contrary to our results, the serum levels of IFN- $\gamma$ in healthy volunteers were similar to levels observed in HCV-infected Polish patients [25], and chronic active hepatitis B patients [26]. This difference may be attributed to the extent of histological liver damage, the activity of the infectious process, assessed by its severity and duration, as well as the difference in the prevalent viral genotype. R-Viso et al. [27] reported significantly lower expression of IFN- $\gamma$ in the biopsy specimens of HCV-infected cases and liver donor controls assessed by immunohistochemistry; this variation may be attributed to the use of different methodology and liver biopsy specimens rather than serum samples.

In the present study, after pegylated IFN- $\alpha$ plus ribavirin treatment, we observed a significant decrease in the serum levels of IFN- $\gamma$, but the levels of IL-17 did not show any statistically significant difference after treatment. This may be explained by the effect of IFN therapy, which induced cytokine shifts. Wang et al. [28] reported that IFN- $\beta$ reduces the expression of Th1-induced cytokines such as IFN and IL-12 while enhancing anti-inflammatory $\mathrm{Th} 2$ responses in patients with multiple sclerosis.

In the current study, we did not find any significant differences in the levels of IFN- $\gamma$ and IL-17 among responders versus nonresponders for pegylated IFN plus ribavirin therapy. Different results were reported by Perrella et al. [29] who found that rapid virological clearance of HCV-RNA in peripheral blood mononuclear cells with a restored and improved $\mathrm{HCV}$-specific IFN- $\gamma$ response was significantly higher in those with a sustained virological response. This discrepancy may be attributed to factors such as the prevalent genotype of the virus as well as the method of assessment of IFN- $\gamma$; we assessed IFN- $\gamma$ in the serum whereas they assessed it intracellularly.

Serum assessment of cytokines has a number of positive aspects, not the least of which is the feasibility of assaying many samples quickly; it also reflects the systemic effects of cytokines and cytokine production by both immune and non-blood cells. However, as a major function of most cytokines is to act in intercellular communication, cytokine levels in serum and plasma provide at best an indirect measure of this key cytokine function [30].

Cytometric, cellular cytokine assessment, although directly reflecting the cytokine function, is laborious and time consuming. Jason et al. [30] examined the relationships between identical serum and cellular cytokines, and concluded that the relationship, although weak, is in a positive direction.

In the present study, a significant positive correlation between serum levels of IFN- $\gamma$ and IL-17 was detected in normal controls and chronic HCV patients before and after therapy. This finding may be attributed to the developmental relationship between Th17 and Th1 cells. Furthermore, Romagnani [31] observed the presence in the circulation of Th cells that can produce IL-17 and IFN- $\gamma$, as well as the flexibility of human Th17 clones to produce IFN- $\gamma$ in addition to IL-17 in response to IL-12, suggesting that there may be a developmental relationship between Th17 and Th1 cells, at least in humans.

\section{Conclusion}

The combined treatment with pegylated IFN- $\alpha$ and ribavirin downmodulated the secretion of key cytokine IFN- $\gamma$ as early as 12 weeks after treatment in the infected host. These results provide an opportunity to evaluate the impact of treatment with pegylated IFN- $\alpha$ and ribavirin on prevention of the immune-driven tissue damage, the hepatic inflammation, and progression to liver cirrhosis in infected patients. However, more work is needed to evaluate the influence of other factors in the response to the treatment. 


\section{References}

$>1$ Mosmann TR, Cherwinski H, Bond MW, Giedlin MA, Coffman RL: Two types of murine helper T cell clone. 1. Definition according to profiles of lymphokine activities and secreted proteins. J Immunol 1986;136: 2348-2357.

-2 Harrington LE, Mangan PR, Weaver CT: Expanding the effector CD4 T-cell repertoire: the Th17 lineage. Curr Opin Immunol 2006; 18:349-356.

$>3$ Wilson NJ, Boniface K, Chan JR, McKenzie BS, Blumenschein WM, Mattson JD, Basham B, Smith K, Chen T, Morel F, Lecron JC, Kastelein RA, Cua DJ, McClanahan TK, Bowman EP, de Waal Malefyt R: Development, cytokine profile and function of human interleukin 17-producing helper T cells. Nat Immunol 2007;8:950-957.

$\checkmark 4$ Ye P, Rodriguez FH, Kanaly S, Stocking KL, Schurr J, Schwarzenberger P, Oliver P, Huang W, Zhang P, Zhang J, Shellito JE, Bagby GJ, Nelson S, Charrier K, Peschon JJ, Kolls JK: Requirement of interleukin 17 receptor signaling for lung CXC chemokine and granulocyte colony-stimulating factor expression, neutrophil recruitment, and host defense. J Exp Med 2001;194:519-527.

$>5$ Higgins SC, Jarnicki AG, Lavelle EC, Mills $\mathrm{KH}$ : TLR4 mediates vaccine-induced protective cellular immunity to Bordetella pertussis: role of IL-17-producing T cells. J Immunol 2006;177:7980-7989.

6 Maek-A-Nantawat W, Buranapraditkun S, Klaewsongkram J, Ruxrungthum K: Increased interleukin-17 production both in helper T cell subset Th17 and CD4-negative $\mathrm{T}$ cells in human immunodeficiency virus infection. Viral Immunol 2007;20:66-75.

7 Molesworth-Kenyon SJ, Yin R, Oakes JE, Lausch RN: IL-17 receptor signaling influences virus-induced corneal inflammation. J Leukoc Biol 2008;83:401-408.

$\checkmark 8$ Hashimoto K, Durbin JE, Zhou W, Collins RD, Ho SB, Kolls JK, Dubin PJ, Sheller JR, Goleniewska K, O’Neal JF, Olson SJ, Mitchell D, Graham BS, Peebles RS Jr: Respiratory syncytial virus infection in the absence of STAT 1 results in airway dysfunction, airway mucus, and augmented IL-17 levels. J Allergy Clin Immunol 2005;116:550-557.

$\checkmark 9$ Annunziato F, Cosmi L, Santarlasci V, Maggi L, Liotta F, Mazzinghi B, Parente E, Filì L, Ferri S, Frosali F, Giudici F, Romagnani P, Parronchi P, Tonelli F, Maggi E, Romagnani $\mathrm{S}$ : Phenotypic and functional features of human Th17 cells. J Exp Med 2007;204:18491861.
10 World Health Organization: Global surveillance and control of hepatitis C. Report of a WHO consultation organized in collaboration with the Viral Hepatitis Prevention Board, Antwerp, Belgium. J Viral Hepat 1999;6:35-47.

11 Hadziyannis SJ, Sette H Jr, Morgan TR, Balan V, Diago M, Marcellin P, Ramadori G, Bodenheimer H Jr, Bernstein D, Rizzetto M, Zeuzem S, Pockros PJ, Lin A, Ackrill AM: Peginterferon-alpha2a and ribavirin combination therapy in chronic hepatitis C: a randomized study of treatment duration and ribavirin dose. Ann Intern Med 2004;140: 346-355.

12 Huang SH, Frydas S, Conti P, Kempuraj D, Barbacane RC, Grilli A, Boucher W, Letourneau R, Papadopoulou N, Donelan J, Madhappan B, Theoharides TC, De Lutiis MA, Riccioni G, Sabatino G: Interleukin-17: a revisited study. Int J Immunopathol Pharmacol 2004;17:1-4.

13 Bowen DG, Walker CM: Adaptive immune responses in acute and chronic hepatitis $\mathrm{C}$ virus infection. Nature 2005;436:946-952.

14 Cramp ME, Rossol S, Chokshi S, Carucci P, Williams R, Naoumov N: Hepatitis C virusspecific $\mathrm{T}$-cell reactivity during interferon and ribavirin treatment in chronic hepatitis C. Gastroenterology 2000;118:346-355.

15 Rowan AG, Fletcher JM, Ryan EJ, Moran B, Hegarty JE, Farrelly CO, Mill KH: Hepatitis $\mathrm{C}$ virus-specific Th17 cells are suppressed by virus-induced TGF- $\beta$. J Immunol 2008;5: 4485-4494.

16 Ishak KG: Chronic hepatitis: morphology and nomenclature. Mod Pathol 1994;7:690693.

17 Tilg H, Wilmer A, Vogel W, Herold M, Nolchen B, Judmaier G, Huber C: Serum levels of cytokines in chronic liver diseases. Gastroenterology 1992;103:264-274.

18 MacDonald AJ, Duffy M, Brady MT, McKiernan S, Hall W, Hegarty J, Curry M, Mills $\mathrm{KH}$ : CD4 T helper type 1 and regulatory $\mathrm{T}$ cells induced against the same epitopes on the core protein in hepatitis $C$ virus-infected persons. J Infect Dis 2002;185:720-727.

19 Neumann-Haefelin C, Blum HE, Chisari FV, Thimme R: T cell response in hepatitis $\mathrm{C}$ virus infection. J Clin Virol 2005;32:75-85.

20 Wherry EJ, Barber DL, Kaech SM, Blattman JN, Ahmed R: Antigen-independent memory CD8 T cells do not develop during chronic viral infection. Proc Natl Acad Sci USA 2004;101:16004-16009.

21 Kanda T, Steele R, Ray R, Ray RB: Inhibition of intrahepatic gamma interferon production by hepatitis $\mathrm{C}$ virus nonstructural protein 5A in transgenic mice. J Virol 2009;83: 8463-8469.
22 Brady MT, MacDonald AJ, Rowan AG, Mills $\mathrm{KH}$ : Hepatitis $\mathrm{C}$ virus non-structural protein 4 suppresses Th1 responses by stimulating IL-10 production from monocytes. Eur J Immunol 2003;33:3448-3457.

23 Hou W, Kang HS, Kim BS: Th17 cells enhance viral persistence and inhibit $\mathrm{T}$ cell cytotoxicity in a model of chronic virus infection. J Exp Med 2009;2:313-328.

24 Oyoshi MK, Elkhal A, Kumar L, Scott JE, Koduru S, He R, Leung DY, Howell MD, Oettgen HC, Murphy GF, Geha RS: Vaccinia virus inoculation in sites of allergic skin inflammation elicits a vigorous cutaneous IL17 response. Proc Natl Acad Sci USA 2009; 106:14954-14959.

25 Inglot M, Gładysz A, Rymer W, Molin I, Zalewska M, Machaj A: Cytokine assessment in untreated hepatitis $\mathrm{C}$ virus infected patients and during interferon alpha +ribavirine therapy. Wiad Lek 2008;61:13-18.

-26 Ge J, Wang K, Meng QH, Qi ZX, Meng FL, Fan YC: Implication of Th17 and Th1 cells in patients with chronic active hepatitis B. J Clin Immunol 2010;30:60-67.

27 R-Viso AT, Duarte MI, Pagliari C, Fernandes ER, Brasil RA, Benard G, Romano CC, Ogusuku S, Cavalheiro NP, Melo CE, Barone AA: Tissue and serum immune response in chronic hepatitis $\mathrm{C}$ with mild histological lesions. Mem Inst Oswaldo Cruz 2010;105:2532.

28 Wang X, Chen M, Wandinger KP, Williams G, Dhib-Jalbut S: IFN- $\beta-1 b$ inhibits IL-12 production in peripheral blood mononuclear cells in an IL-10-dependent mechanism: relevance to IFN-beta-1b therapeutic effects in multiple sclerosis. J Immunol 2000;165: 548-557.

29 Perrella A, Sbreglia C, Atripaldi L, Esposito C, D’Antonio A, Perrella O: Rapid virological response in peripheral blood mononuclear cells with an increase of hepatitis $C$ virusspecific interferon-gamma production predisposes to sustained virological response in patients with chronic hepatitis $\mathrm{C}$ genotype 1 undergoing treatment with pegylated-interferon alpha 2 a plus ribavirin. Scand J Gastroenterol 2010;45:250-255.

30 Jason J, Archibald LK, Nwanyanwu OC, Byrd MG, Kazembe PN, Dobbie H, Jarvis WR: Comparison of serum and cell-specific cytokines in humans. Clin Diagn Lab Immunol 2001;8:1097-1103.

31 Romagnani S: Human Th17 cells. Arthritis Res Ther 2008;10:206. 